\title{
Pathways towards Women Empowerment and Determinants of Decent Work Deficit: A South Asian Perspective
}

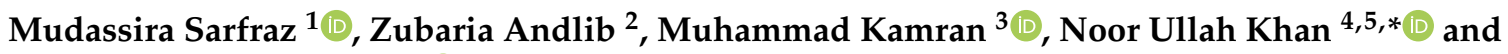 \\ Hanieh Alipour Bazkiaei 4 (iD \\ 1 Faculty of Management, University of Warsaw, 02-678 Warsaw, Poland; msarfraz@wz.uw.edu.pl \\ 2 Department of Economics, Federal Urdu University of Arts, Science and Technology, \\ Islamabad 44000, Pakistan; zubaria.andlib@fuuast.edu.pk \\ 3 Department of Management, Warsaw University of Business, 00-389 Warsaw, Poland; \\ muhammad.kamran@wwsb.edu.pl \\ 4 Faculty of Entrepreneurship and Business, Universiti Malaysia Kelantan (UMK), Taman Bendahara, \\ Pengkalan Chepa 16100, Malaysia; louie.utm.20@gmail.com \\ 5 Department of HRM, NUST Business School, National University of Sciences and Technology, Scholars Ave, \\ H-12, Islamabad 44000, Pakistan \\ * Correspondence: noorullah@umk.edu.my
}

Citation: Sarfraz, Mudassira, Zubaria Andlib, Muhammad Kamran, Noor Ullah Khan, and Hanieh Alipour Bazkiaei. 2021. Pathways towards Women Empowerment and Determinants of Decent Work Deficit: A South Asian Perspective. Administrative Sciences 11: 80. https://doi.org/10.3390/ admsci11030080

Received: 23 June 2021

Accepted: 3 August 2021

Published: 9 August 2021

Publisher's Note: MDPI stays neutral with regard to jurisdictional claims in published maps and institutional affiliations.

Copyright: (c) 2021 by the authors. Licensee MDPI, Basel, Switzerland. This article is an open access article distributed under the terms and conditions of the Creative Commons Attribution (CC BY) license (https:// creativecommons.org/licenses/by/ $4.0 /)$.

\begin{abstract}
This research aims to assess the household and individual-level factors, specifically education, that affect the probability of women being engaged in decent work activities in the labor market. The study utilized the most recent labor force survey data from Pakistan with a sample size of 64,009 women. The research exploits the multinomial logit model (MNL) for data analysis. Several studies exist on the causes of female labor force participation nationally-in Pakistan-and internationally. However, there is a lack of research exploring the link between women's access to decent work and various household and individual-level characteristics. This study intends to fill this literature gap by exploiting the largest nationwide labor force survey and exploring how household and individual-level factors, specifically focusing on women's education level, relate to women's employment status categories. The study's findings reveal that education plays an essential role in uplifting women for better employment opportunities, i.e., educated women are more likely to be engaged in decent labor market activities such as paid employees and employers. The findings of the study propose some significant policy implications. E.g., (i) since education is the key to open better and decent work opportunities, it is crucial for women and their household heads to invest in education and vocational training; (ii) there is a dire need to have a policy shift in providing women access to at least a higher secondary (HS) level of education in Pakistan. The rationale is that less educated and illiterate women are concentrated in vulnerable employment; and (iii) at a micro level, there is a need to bring awareness among male household heads, specifically in rural areas, to realize that working women should not be considered a social stigma for the household.
\end{abstract}

Keywords: women's employment status; education; decent work deficit; South Asia

\section{Introduction}

The idea of decent work was initiated by International Labor Organization along with United Nations two decades ago (UN 1997). These organizations have been working on setting the minimum standards for promoting decent work and its evaluation. According to the ILO (2008), decent work is central to reducing poverty and achieving sustainable development. On these lines, decent work deficits include different forms of underemployment, poor quality jobs, insecure income, rights that are denied, and gender inequality. The fact that women have a higher share of agricultural employment than men in Pakistan raises the issue of persistent more inferior quality of jobs for women and lower labor force participation which is considered as one of the significant indicators 
to measure the socio-economic development of any country (Lechman and Kaur 2015). Specifically, an increasing trend in female labor force participation (FLFP) indicates an improvement in economic as well as the social condition of a nation because it aids to empower women, reduction in gender-based disparities and enhances the utilization of the workforce (women) as well as boost the economic growth of the country (ILO 2016). Several constructive outcomes are directly related to women's economic participation, such as educational attainment, improvement in food and nutrition, and decision-making at the household level (UN Women Pakistan 2016).

The employment status of an individual describes an individuals' socio-economic condition and conditions of work. The employment statuses are segregated into four broader categories, "employer" (EMP), "paid employees" (EMPLEE), "own-account workers" (OAW), and "contributing family worker" (CFW). Unfortunately, many women are concentrated in vulnerable employment that is comprised of two categories of OAW and CFW (GoP 2018). It is important to discuss different policy choices for resource-constrained countries such as Pakistan to uplift a sizeable proportion of the female labor force from vulnerable employment to non-vulnerable employment categories. Education is the most critical channel. As such better-educated women can apply and opt for better employment opportunities. We can find evidence from the literature that education is positively associated with female labor market outcomes (Faridi et al. 2009). Apart from education, women's fertility may also interrupt their career progression and the availability of decent work opportunities for them. Moreover, societal gender norms make women face the burden of childbearing and child-rearing, which in turn lowers their availability for decent work (Finlay 2021).

Concerning the gendered division of the labor force in Pakistan, it is observed that there are $22 \%$ women in the labor force and $78 \%$ are out of the labor force. In contrast, for men, this distribution is $68 \%$ and $32 \%$ for those who are in the labor force and not in the labor force, respectively. However, there are 5\% unemployed men and $9 \%$ unemployed women (GoP 2018). According to the World Bank (2017), the FLFP rate is the lowest in Pakistan among South Asian Countries. FLFP not only varies on a national basis but also, there are substantial variations at the rural-urban and provincial levels. The data for regional and provincial FLFP rates shows that females' inadequate access to labor market opportunities and social and cultural constraints are the most significant causes of the lower rate of FLFP in urban areas and rural areas of Pakistan (GoP 2018).

Figure 1 shows the regional situation of the female labor force participation rate in Pakistan. It is observed that the FLFP rate shows an increasing trend. During 2001-2002 FLFP rate was $14.4 \%$, and in 2014-2015 it was $22.2 \%$, which is considered a sluggish and fixed rate of increase in FLFP. In 2001-2002 the FLFP rate for rural areas was $16.8 \%$, and in 2014-2015 it was $28.8 \%$, whereas, in urban areas, in 2001-2002, the FLFP rate was 10\%, and in 2014-2015 it was 10\% which is the constant trend. One of the main reasons behind the rural FLFP rate is the presence of a high rate of unpaid workers, almost $55 \%$ of the total FLFP in Pakistan. In Figure 2, we plotted the year-wise trends of four employment statuses for women. We observed from the figure that most of the women are working as CFW.

Figure 3 shows the FLFP rate in South Asia. With 22\% FLFP, Pakistan ranks the lowest among countries in South Asia. There are several reasons for the low rate of FLFP, which are essential to understand to improve the situation. Gender disparity, low levels of education, and lack of women's empowerment are the most significant variables directly associated with women's participation in the labor force (Qian 2008). For women to participate actively in the labor force, it is necessary to control the social, structural, and cultural barriers. It is imperative to focus on the education of women to increase female labor force participation. In addition, education helps women to opt for better and well-paid employment opportunities. This study mainly aims to highlight how different levels of education are associated with varying statuses of employment in Pakistan. Besides, the other objective of the study is to figure out various factors at the individual and the household level that relate to different employment statuses of women at the regional and 
provincial levels in Pakistan. For this purpose, we utilized the latest available data from the Labor Force Survey of Pakistan.

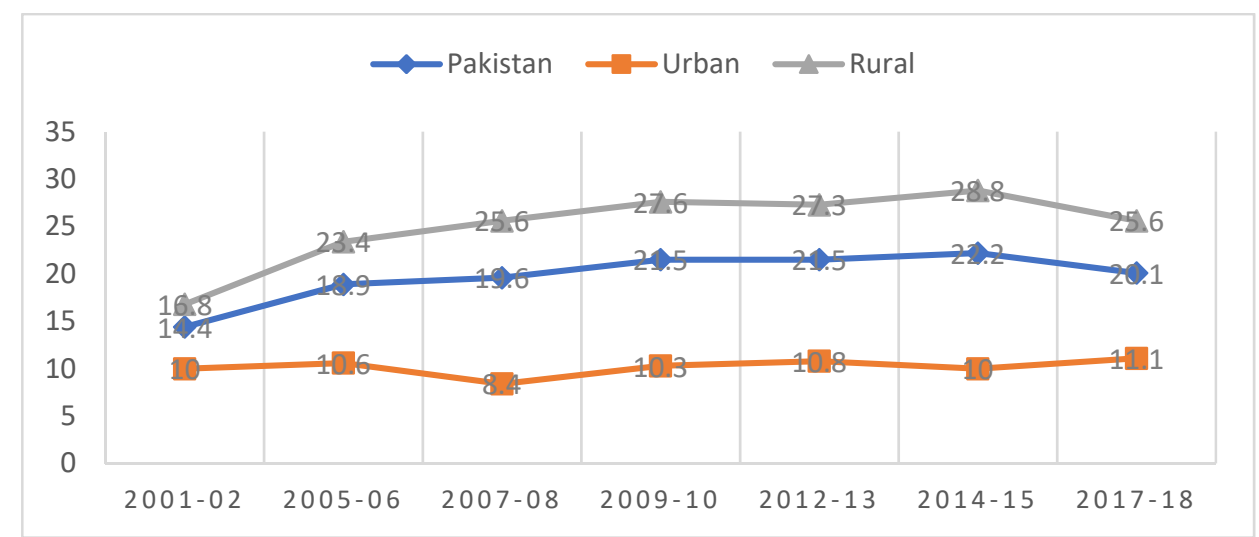

Figure 1. Region-wise and overall trends in the FLFP rate. Source: LFS survey various reports.

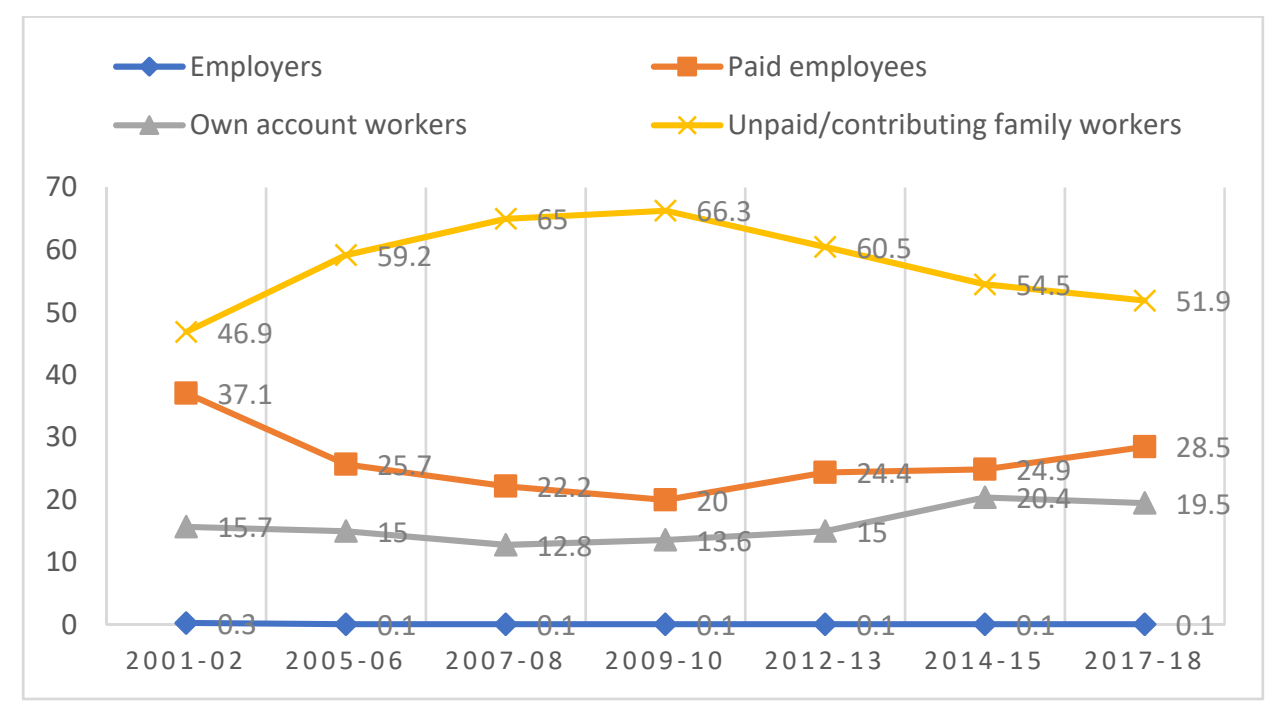

Figure 2. Trends in female employment statuses by LFS survey years. Source: LFS various reports.

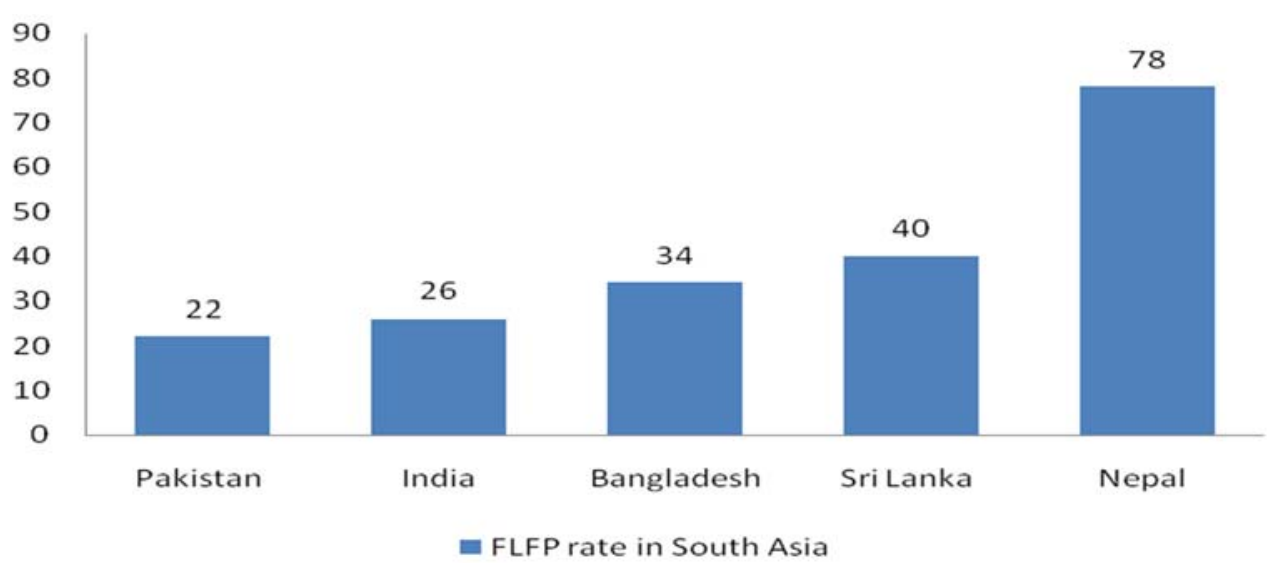

Figure 3. South Asian FLFP rate. World World Bank (2017).

The basic theme of the paper is that Section 2 emphasizes the extant literature present at the national and international level related to the topic of discussion. Section 3 explains the main methodology adopted in the study. Section 4 focuses on the operationalization of 
variables, their relations, and the data taken from various sources. Section 5 presents the empirical findings. Section 6 includes the summary of the study in the form of a conclusion and provides some policy implications to improve the quality of employment among women in Pakistan.

\section{Literature Review}

In the prior literature, two complementary theoretical approaches support the proposition of the FLFP. However, both of these approaches focus on different aspects of labor supply decisions. On one hand, the neoclassical model of allocation of time, (Becker 1965) illustrates that a woman will compare two alternative uses of time, whether a woman enters the labor market or stays at home and spent her time in domestic activities. On the other hand, the human capital investment theory (Becker 1975) stresses the relationship between the returns on the investment of acquiring valuable skills and the time the person, in a particular context a woman, expects to allocate in labor market activities during her entire life span. In other words, labor force participation outcomes are related to general skills acquired through education and training (Blundell et al. 1999). Indeed, those who are planning to participate in the labor market as full-time workers are prompted to invest more in education and training. Moreover, the human capital model emphasizes the role of women's preferences and the choices they may make to invest in education and training (Mitra and Singh 2006), as well as to spend a smaller share of their adult years in the labor force (Blau et al. 2005). Other factors include premarket discrimination, or societal discrimination, in which various types of social pressures influence women's choices adversely (Khoudja and Fleischmann 2015).

There is ample empirical evidence available in the literature that examines the factor affecting women's labor market participation. In this section, we present the review of this available literature with a specific focus on the role of education, household and individual characteristics in affecting FLFP in general and decent work in particular. Aly and Al-Quisi (1996) observed different factors at the individual and the household level that have a significant impact on FLFP in Kuwait. It is concluded that wage rate and women's education positively influence women's decision to labor force. On the other hand, marital status, number of children, old persons in the home, and their age negatively impact FLFP decisions in Kuwait.

Hafeez and Ahmad (2002) conducted a study on Pakistan and found that women's education levels, age, and household size have a positive relationship with the FLFP rate. In contrast, the household's income and the value of the financial assets negatively impact females' participation in the labor force. Assaad and Zouari (2003) observed that marital status, young children, and old age family members are significant obstacles in the way of women's employment decisions. Moreover, Ejaz (2007) are of the view that marital status, husbands' earning, age, education of the women, access to vehicle facility, and the number of young and school-going children are the most significant factors which influence women's decisions to participate in job activities.

There is a diminishing trend in the FLFP rate among married and educated women who belong to 25-54 age groups from 1994 to 2004 in the USA (Bradbury and Katz 2005). It is observed that the most significant factor behind this low rate of FLFP includes the number of kids in the household, household head income, and low wages offered to the women as compared to their male competitors. Similarly, cultural norms and trends also play a significant role in the low rate of female participation in the labor force. Ntuli (2007) mainly focuses on the influential factors affecting the FLFP decision in South Africa. The study results show that female education levels are significantly associated with women's decisions for labor market activities in South Africa. Whereas income from other sources, number of children at home, the geographical situation of the area, and marital status of the women have a significantly negative effect on female's decision to enter the labor force. It is also stated that women have more chances to indulge in job activities if they belong to nuclear families. 
The area of residence of a woman is also critical to women's engagement in Labor market activities. Uraz et al. (2010) observed that women from urban areas are more likely to have an interest in the labor market than females from rural areas. Highly educated women are more likely to contribute to the labor market. With an increase in household head education and wealth, women are less likely to be part of the job market. Lee et al. (2008) examined the relationship between the marital status of women and the rate of FLFP in Korea. According to the findings of the study, it is observed that there are two major obstacles that women are facing to participate in labor market activities (1) most women do not take part in labor market activities because of the non-availability of daycare facilities and (2) employment status of spouse also determines women's employment preferences. The study also explains that the decline in FLFP rate among married females results from demand-side factors.

Bhalla and Kaur (2011) examined various aspects of the low rate of FLFP in the region of India. The study's findings suggest some significant conclusions for the policymakers, and these include an increase in the wage rate has positive and significant impacts on the FLFP rate. The study offers an inverted U-shaped association between wages and FLFP. The higher level of female education has positive effects on FLFP but, the higher level of male education has negative consequences on the FLFP rate in India. If male partners earn well, females are less likely to choose to work. In another study by Klasen and Pieters (2015), it is observed that the key reasons behind the low FLFP rate in the urban areas of India are both demand and supply-side factors. Factors included on the supply side are the higher level of the husband's education and having a satisfactory job. On the other hand, demand-side factors include low expansion of appropriate job opportunities for females which cause most of the urban women to stay away from the labor force in India.

Saha and Kalita (2015) analyzed the most significant reasons that directly impact women's decision to employment in Tripura. It is found that women's decision to participate in the labor force is negatively associated with the income of the other family members. In addition, marital status and large family size negatively affect the FLFP rate in India. Pignatti et al. (2017) examined FLFP for young women of age between 15 to 25 years in Georgia from 2003 to 2015 . It is observed that marital status negatively impacts female participation in the labor force. It is found that migrant women are more likely to be in the labor force. However, large family size and the number of young children exert negative impacts on the female's decision to participate in the workforce.

Concerning women's access to decent work, research on pre-and-post policy analysis of Jordanian Decent Work Country Programme (DWCP) found that the program has remained ineffective in increasing female participation in the labor market and increase in social security corporation because of decent work deficiency (Abu-Hummour 2021). The availability of decent work among women is also analyzed concerning how a particular sector is positioned globally. In Indonesia, it is found that characteristics of firms related to their share in global production affect decent work outcomes for men and women and that foreign direct investment (FDI) and exports have different effects on men and women (Osterreich 2020).

Based on our previous illustration of different theories and empirical work performed by different researchers. Now, we are able to formulate a different hypothesis that we are intending to check in our study.

Hypothesis 1a. Education exerts a positive influence on decent employment.

Hypothesis 1b. Education does not exert a positive influence on decent employment.

Hypothesis 2a. Head of the household's education exerts a positive influence on decent employment.

Hypothesis $\mathbf{2 b}$. Head of the household's education does not exert a positive influence on decent employment. 
Hypothesis 3a. Region and province of residence of women influence decent employment.

Hypothesis $\mathbf{3 b}$. Region and province of residence of women do not influence decent employment.

We specified three hypotheses; our first hypothesis is related to the education of women and its interconnectedness with decent employment. The previous literature elucidates that education is the most effective way for an individual woman to opt for better occupations, thus it helps to obtain decent employment among women (Andlib and Khan 2019). Further, our second hypothesis is concerned with the head of the household characteristics. We included the head of the household's education. If the head of the household is highly educated then there are more chances that he/she must be earning well. It has put two different effects on women's employment decisions. Highly educated heads most likely encourage women to take part in labor market activities but on the other hand, highly educated heads are more likely to earn well and they do not encourage women to take part in labor market activities (Che and Sundjo 2018). In addition, the place of residence exerts a significant influence on women's employment status. Most urban women are more likely to opt for white-collar jobs as they have come across many opportunities. On the contrary, rural women have to face many challenges to opt for better employment statuses. As in Pakistan, the majority of the rural women are engaged in the agriculture sector as OAW (Andlib and Khan 2018).

This research is primarily based on the neoclassical model of allocation of time, (Becker 1965) and human capital investment theory (Becker 1975). These theories were tested by several empirical studies such as (Aly and Al-Quisi 1996; Hafeez and Ahmad 2002; Ntuli 2007; and Andlib and Khan 2019). The results of these studies are essentially in line with the prediction of two theories presented by Becker.

By looking at the previous literature, we can conclude that several studies on causes of female labor force participation nationally in Pakistan and internationally. However, there is a lack of research exploring the link between women's access to decent work and various household and individual-level characteristics. This study intends to fill this literature gap by exploring how household and individual-level factors, with a specific focus on women's education level, relate to women's employment status categories.

\section{Methodology-The Multinomial Logit Model}

As the variable of interest in this research is women's employment status, which is a discrete variable, therefore, we employ the multinominal logit (MNL) model to analyze the employment status of women. There are four categories of employment status, i.e., EMP, EMPLEE, OAW, and CFW, with the base category of woman who is neither currently working nor looking for work in the labor market. A selected woman $i$ is considered to choose among these four employment choices $j=1,2,3$, and 4 , conditional on a set of explanatory variables $x$, as given in the expression below:

$$
y_{i j}=\hat{x}_{i j} \beta+e_{i j}
$$

$X_{i j}$ is a vector of explanatory variables of the given four alternative employment statuses, 1 to 4 , that influences the utility of the selected woman who is participating in labor market activities. The $e_{i j}$ Represents the error terms that explain those characteristics that are unmeasured in our econometric model. In the MNL model (Greene 2000) ${ }^{1}$, we will estimate coefficients $\beta^{(0)}, \beta^{(1)}, \beta^{(2)}, \beta^{(3)}$ and $\beta^{(4)}$. These coefficients are related to each employment status. The dependent variable will take one out of four mutually exclusive and exhaustive values $j=1,2,3$, and 4 :

$$
\operatorname{Prob}(y=0)=\frac{e^{\beta^{(0) \prime} x}}{e^{\beta^{(0) \prime} x}+e^{\beta^{(1) \prime} x}+e^{\beta^{(2) \prime} x}+e^{\beta^{(3) \prime} x}+e^{\beta^{(4) \prime} x}}
$$




$$
\begin{aligned}
& \operatorname{Prob}(y=1)=\frac{e^{\beta^{(1) \prime} x}}{e^{\beta^{(0) \prime} x}+e^{\beta^{(1) \prime} x}+e^{\beta^{(2) \prime} x}+e^{\beta^{(3) \prime} x}+e^{\beta^{(4) \prime} x}} \\
& \operatorname{Prob}(y=2)=\frac{e^{\beta^{(2) \prime} x}}{e^{\beta^{(0) \prime} x}+e^{\beta^{(1) \prime} x}+e^{\beta^{(2) \prime} x}+e^{\beta^{(3) \prime} x}+e^{\beta^{(4) \prime} x}} \\
& \operatorname{Prob}(y=3)=\frac{e^{\beta^{(3) \prime} x}}{e^{\beta^{(0) \prime} x}+e^{\beta^{(1) \prime} x}+e^{\beta^{(2) \prime} x}+e^{\beta^{(3) \prime} x}+e^{\beta^{(4) \prime} x}} \\
& \operatorname{Prob}(y=4)=\frac{e^{\beta^{(4) \prime} x}}{e^{\beta^{(0) \prime} x}+e^{\beta^{(1) \prime} x}+e^{\beta^{(2) \prime} x}+e^{\beta^{(3) \prime} x}+e^{\beta^{(4) \prime} x}}
\end{aligned}
$$

However, the model is unidentified because there is more than one solution to $\beta^{(0)}$, $\beta^{(1)}, \beta^{(2)}, \beta^{(3)}$ and $\beta^{(4)}$ which leads to the probabilities $y=0, y=1, y=2, y=3$ and $y=4$. To make the model identified, we will have to define a base category; set $\beta^{(0)}=0$ (the selected woman is not currently working in the labor market). The rest of the coefficients $\beta^{(1)}, \beta^{(2)}, \beta^{(3)}$ and $\beta^{(4)}$ find out the relative change to the $y=0$ which is when a woman is not working. Hence, setting $\beta^{(0)}=0$ the equations become:

$$
\begin{aligned}
& \operatorname{Prob}(y=0)=\frac{1}{1+e^{\beta^{(1) \prime} x}+e^{\beta^{(2) \prime} x}+e^{\beta^{(3) \prime} x}+e^{\beta^{(4) \prime} x}} \\
& \operatorname{Prob}(y=1)=\frac{1}{1+e^{\beta^{(1) \prime} x}+e^{\beta^{(2) \prime} x}+e^{\beta^{(3) \prime} x}+e^{\beta^{(4) \prime} x}} \\
& \operatorname{Prob}(y=2)=\frac{1}{1+e^{\beta^{(1) \prime} x}+e^{\beta^{(2) \prime} x}+e^{\beta^{(3) \prime} x}+e^{\beta^{(4) \prime} x}} \\
& \operatorname{Prob}(y=3)=\frac{1}{1+e^{\beta^{(1) \prime} x}+e^{\beta^{(2) \prime} x}+e^{\beta^{(3) \prime} x}+e^{\beta^{(4) \prime} x}} \\
& \operatorname{Prob}(y=4)=\frac{1}{1+e^{\beta^{(1) \prime} x}+e^{\beta^{(2) \prime} x}+e^{\beta^{(3) \prime} x}+e^{\beta^{(4) \prime} x}}
\end{aligned}
$$

Ultimately, the relative probability of a woman being employed concerning the reference category (not working and neither looking for work) is as under:

$$
\frac{\operatorname{Prob}(y=1)}{\operatorname{Prob}(y=0)}=e^{\beta^{(1) \prime} x}
$$

The prime reason for applying the MNL model is that it directly estimates the probability of a woman being in a particular labor market state as a function of the observed characteristics.

$$
\operatorname{Prob}(y=j)=\frac{e^{\beta^{j^{\prime} x}}}{\sum_{k=0} e^{\beta^{k \prime} x}} j=1,2, . ., j
$$

In case of only one choice when $j=1$, we have the binomial logit model:

$$
\operatorname{Prob}(y=1)=\frac{e^{\beta^{\prime \prime} x}}{1+e^{\beta^{k \prime} x}}
$$

The derivation of the $\log$-likelihood function when $d_{i j}=1$ is defined as; if the individual $i$ chooses an option $j$, and 0 if not, for the remaining $j-1$ outcomes. It means for each individual, only one of the $d_{i j} / s$ is 1 . The log-likelihood is a generalization of the binomial logit model:

$$
\ln (L)=\sum_{i=1}^{n} \sum_{j=1}^{j} d_{i j} \times \ln
$$

This analysis will consider five possible outcomes (employment statuses of a woman, i.e., paid employee, employer, own-account worker, and contributing family worker 
whereas women not working neither looking for work is the base category) for women workers. Although the MNL model is useful for analyzing the multiple response categorical variables, however, the model does not consider the true causal relationship between the dependent and independent variable of interest.

\subsection{The Marginal Effects (MEs)}

As opposed to ordinary least squared regression, the coefficients of MNL models are challenging to interpret. However, we will calculate the MEs to interpret the regression results. The $\mathrm{ME}$ is the derivative of the probability concerning the different explanatory variables.

$$
\begin{aligned}
& \operatorname{Prob}(y=j)=\frac{e^{\beta^{j} x_{i}}}{\sum_{k=0} e^{\beta^{k /} x_{i}}} \text { with respect to } x \text { to find } \\
& \qquad \frac{\partial P^{j}}{\partial x^{i}}=P^{j}\left[\beta^{j} \sum_{k=0}^{j} P^{k} \beta^{k}\right]=P^{j}\left[\beta^{j}-\hat{\beta}\right]
\end{aligned}
$$

The ME is defined as "the effect of a one-unit change in an explanatory variable from its sample average on the probability of being in each of the employment statuses, holding all other variables at their average value". (Gray et al. 2002).

The general form of the model of employment statuses of women is:

$$
y_{i}=\alpha+\beta X+\varepsilon
$$

whereas $y_{i}$ will take different values for each category of employment status ( 1 for EMPLEE, 2 for EMP, 3 for OAW, and 4 for CFW), and it is 0 if she is neither working nor seeking work. $X$ represents the vector of regional and household level characteristics of selected women, and $\varepsilon$ is the error term.

\subsection{Data and Operationalization of Variables}

Labor Force Surveys are an essential source of data for any analysis based on the labor market. In this study, we use the latest available dataset of LFS 2017-2018, from where we obtained the data for our variable of interest and other control variables. We followed the standardized categorization of the employment status of women into four categories, namely EMPLEE, EMP, CFW, and OAW. In contrast, the reference category is those women who are neither working in the labor market nor looking for work. We exclude women currently enrolled in primary, secondary, or tertiary level education. The final sample for the analysis of decent work deficit determinants among women comprises 64,009 women. A detailed description of dependent variables and other control variables used for the analysis is presented in Table 1.

Table 1. Definitions of variables.

\begin{tabular}{cc}
\hline Variables & Definition \\
\hline \multirow{2}{*}{ Employment Status } & Dependent variable \\
\cline { 2 - 2 } & $=1$ if the paid employee \\
\cline { 2 - 2 }$=2$ if the employer & $=3$ if own account worker \\
\hline (reference category: neither working nor seeking work). \\
\hline Age & Main explanatory variables \\
\hline Women's Characteristics \\
\hline
\end{tabular}


Table 1. Cont.

\begin{tabular}{|c|c|}
\hline Variables & Definition \\
\hline Age squared & Square of age \\
\hline Married & $=1$ if ever married (reference category: never married) \\
\hline Prim & $=1$ if primary education. \\
\hline Mid & $=1$ if middle education \\
\hline Secondary & $=1$ if matric education \\
\hline HS & $=1$ if higher secondary education \\
\hline Grad & $=1$ if graduation \\
\hline Tertiary & $=1$ if above graduation; (reference category: No formal education). \\
\hline TVT & $=1$ if technical/vocational training \\
\hline Local & $=1$ if living in the province since birth. \\
\hline Migrated (inter/intra province) & $=1$ if migrated inter-province or intra-province \\
\hline & Household Head Characteristics \\
\hline Female Head of $\mathrm{HH}$ & $=1$ if the female is $\mathrm{HH}$ head (reference category: Male $\mathrm{HH}$ head) \\
\hline Age & Age of $\mathrm{HH}$ head \\
\hline No formal education & Head has no formal education \\
\hline Some Education & Some Education \\
\hline Emp & $=1$ if the head is an employer. \\
\hline Emplyd & $=1$ if the head is paid, employee \\
\hline Self emplyd & $=1$ if the head is self-employed. \\
\hline Own account & $=1$ if the head is own account worker \\
\hline Contributing Worker & $\begin{array}{l}=1 \text { if the head is contributing family worker. (reference category: head neither working nor } \\
\text { looking for work). }\end{array}$ \\
\hline & Family Characteristics: \\
\hline Household size & HH size \\
\hline Kids & Number of kids of $0-5$ years \\
\hline Extended family & $=1$ if extended family (reference category: nuclear family). \\
\hline & Region \\
\hline Urban & $=1$ if woman belongs to urban area. (reference category: rural area). \\
\hline Punjab & $=1$ if belongs to Punjab \\
\hline Sindh & $=1$ if belongs to Sindh \\
\hline KPK & =1 if belongs to KPK (reference category: Balochistan). \\
\hline
\end{tabular}

\section{Results Interpretations}

Table 2 presents the summary statistics of variables used for examining the employment statuses of women. The average age of women with the employment category of "paid employee" and "contributing family worker" is 33 years in our selected sample. However, it is higher, i.e., 36 years in women EMP, which is justified because it takes time and experience for any individual woman to become an employer. For own account worker average age of the selected woman is 35 years. Almost $85 \%$ of ever-married women work as own-account workers, and nearly $80 \%$ of ever-married women are working as CFW. Ever married women are predominantly engaged in these two employment statuses.

Education is one of the crucial determinants of FLFP. Unfortunately, the bulk of the women with no formal education is working as EMPLEE $(50 \%)$, thus causing a further 
increase in vulnerable employment. From the rest of the 50\% women, only $10 \%$ and $11 \%$ women with graduation and a higher level of education, respectively, are working as EMPLEE. Even though the employer's category carries only a $2 \%$ share in overall employment statuses, it is presenting an optimistic picture as compared to other employment statuses, such as a sizeable share of $43 \%$ of women with higher education is working as EMP in our selected sample of the employment status of women. In the rest of the two employment statuses, a vast majority of women $(70 \%$ and $82 \%)$ with no formal education are working as OAW and CFW.

$41 \%$ of women in the sample who are OAW have received technical/ vocational training, whereas this percentage is $24 \%$ of women working as paid employees. In case of migration, $16 \%$ EMPLEE women have migrated to a province where they are currently working and residing. In contrast, the proportion for migrated women is $12 \%$ in the case of EMP and own-account workers. Only $8 \%$ of women have migrated from other provinces and are working as unpaid/contributing workers in our selected sample.

Concerning household head gender, for every employment status of women, most households are headed by a male member of the family. In a traditional society such as Pakistan, a male is supposed to be the head of the household. If a woman becomes an orphan, widowed, or divorced, the youngest brother or son is most likely to take the position of his father. Still, there is less social acceptability for a woman to become the head of the household.

We also included the household head education in our analysis of the employment status of women. We come to know that majority of the heads possess no formal education in our selected sample, i.e., $47 \%$ in case of women EMPLEE, $51 \%$ in case of own-account workers, and $60 \%$ in case of females CFW, but the situation is different for women who are working as EMP in our selected sample, a vast majority of heads of the households possess matric and above levels of education.

In the descriptive analysis, we found few interesting insights concerning the father's employment status. In the case of women working as EMPLEE, most of their heads of the household are also working as EMPLEE. In contrast, if women are engaged in labor market activities either as OAW or CFW, then a sizeable proportion of their household heads are also working as OAW.

The average household size is seven for women who are working as OAW or CFW. The number of the youngest children at home also affects women's availability for labor market activities. In our selected sample majority of the employed women who are working either as OAW or as CFW has the youngest children at home. With respect to the type of family women belong to, almost $58 \%$ of paid employed women are living in the nuclear family system. On the contrary, only $38 \%$ of women working as EMP live in a nuclear family system, whereas this proportion is $60 \%$ and $55 \%$ for OAW and CFW women, respectively.

A vast majority of women working as EMP; are from urban areas, whereas $96 \%$ of CFW are from rural areas. According to the data, $75 \%$ of EMPLEE women reside in Punjab province while $8 \%$ are residing in KPK, $12 \%$ live in Sind province, and $2 \%$ live in Balochistan. The descriptive statistics reveal that Punjab and Sind are those provinces where most of the women who are working as EMPLEE reside. The same pattern is seen in the case of EMP too, where many women working as EMP are living in the Punjab province. In the case of own-account workers and unpaid/CFW, $61 \%$ and $59 \%$ of women living in Punjab province, whereas 23\% of CFW are from Sindh province and 16\% women are working as own account working are residing in the KPK province. 
Table 2. Summary statistics of variables.

\begin{tabular}{|c|c|c|c|c|}
\hline Explanatory Variables & EMPLEE & EMP & OAW & CFW \\
\hline \multicolumn{5}{|c|}{ Women's Characteristics } \\
\hline Age & 33.201 & 36.938 & 35.196 & 33.278 \\
\hline Agesq & 1236.782 & 1532.188 & 1369.577 & 1265.982 \\
\hline Never married & 0.294 & 0.313 & 0.147 & 0.202 \\
\hline Married & 0.706 & 0.687 & 0.853 & 0.798 \\
\hline No formal education & 0.505 & 0.063 & 0.708 & 0.828 \\
\hline Prim & 0.094 & 0.001 & 0.136 & 0.101 \\
\hline Mid & 0.046 & 0.001 & 0.06 & 0.037 \\
\hline Secondary & 0.074 & 0.121 & 0.055 & 0.024 \\
\hline HS & 0.065 & 0.063 & 0.018 & 0.006 \\
\hline Grad & 0.106 & 0.313 & 0.014 & 0.003 \\
\hline Tertiary & 0.11 & 0.438 & 0.009 & 0.001 \\
\hline TVT & 0.244 & 0.188 & 0.418 & 0.185 \\
\hline No TVT & 0.756 & 0.812 & 0.582 & 0.815 \\
\hline Local & 0.833 & 0.875 & 0.879 & 0.917 \\
\hline Migrated (inter/intra province) & 0.167 & 0.125 & 0.121 & 0.083 \\
\hline \multicolumn{5}{|c|}{ Household Head Characteristics } \\
\hline Male & 0.86 & 0.937 & 0.828 & 0.976 \\
\hline Female & 0.14 & 0.063 & 0.172 & 0.024 \\
\hline Age & 46.967 & 50.250 & 44.725 & 46.815 \\
\hline No formal education & 0.47 & 0.02 & 0.51 & 0.59 \\
\hline Some Education & 0.23 & 0.06 & 0.30 & 0.29 \\
\hline 10 years or more Edu & 0.28 & 0.92 & 0.11 & 0.11 \\
\hline Emp & 0.010 & 0.250 & 0.005 & 0.003 \\
\hline Emplyd & 0.5 & 0.131 & 0.35 & 0.111 \\
\hline Own account & 0.339 & 0.22 & 0.526 & 0.835 \\
\hline Contributing worker & 0.007 & 0.125 & 0.008 & 0.012 \\
\hline Neither working nor looking for work & 0.154 & 0.524 & 0.111 & 0.042 \\
\hline \multicolumn{5}{|c|}{ Family Characteristics: } \\
\hline Household size & 6.735 & 6.250 & 7.113 & 7.635 \\
\hline Kids & 0.873 & 0.937 & 1.207 & 1.297 \\
\hline Nuclear Family & 0.577 & 0.375 & 0.596 & 0.545 \\
\hline Extended Family & 0.422 & 0.625 & 0.403 & 0.455 \\
\hline \multicolumn{5}{|c|}{ Region } \\
\hline Urban & 0.372 & 0.750 & 0.187 & 0.036 \\
\hline Rural & 0.628 & 0.250 & 0.813 & 0.964 \\
\hline Punjab & 0.755 & 0.699 & 0.612 & 0.592 \\
\hline Sindh & 0.129 & 0.156 & 0.055 & 0.237 \\
\hline KPK & 0.088 & 0.142 & 0.165 & 0.054 \\
\hline Balochistan & 0.028 & 0.003 & 0.168 & 0.117 \\
\hline
\end{tabular}




\section{Discussion and Findings}

The results of the multinomial estimation are presented in Table 3. As compared to a woman who is not working nor seeking work, for every other employment status as the age of a woman increases, then there is more probability that she will be working as a paid employee, employer, own-account worker, or contributing family worker. Age squared has a negative sign in every employment status; it means that age has an inverted U-shape pattern for every employment status. As the age of the woman increases, then there is less probability for her that she will be working in any of the above-mentioned employment statuses (Faridi et al. 2009; Shaheen et al. 2015; Usman and Sanusi 2016).

There is a vast literature on the effect of marital status on FLFP, for example, Faridi et al. (2009); Ntuli (2007); Shaheen et al. (2015). Compared to a never-married woman, if a woman is ever married, there is less probability that she will be working as a paid employee or an employer, but there is more probability that she is working as an own-account worker or an unpaid/contributing family worker. Similar results are presented by other studies such as (Ejaz 2007; Varol 2017).

To see the impact of residential status on the employment statuses of women, we included regional and provincial distributions in our analysis. The analysis shows that as compared to those women who are not working, in the case of EMPLEE and EMP there is more probability that women are residing in urban areas as compared to the base category rural areas. In contrast, in the case of OAW and CFW, there are fewer probabilities that women live in urban areas than in the base category rural areas.

Punjab province is performing better in terms of human development indicators than the rest of the three provinces in the country, whereas Balochistan province is the worst in this regard (UNDP 2017). The same is true in our provincial analysis. As compared to not working women, most women who are working as EMPLEE, OAW, and CFW are residing in province Punjab. In the case of EMPLEE, as compared to the base category, not working women, there is less probability that women live in the province of KPK and Sindh as compared to the base category province Balochistan, but it is insignificant. The empirical findings also revealed heterogeneity among women with respect to region and province of residence and their decent employment status. Urban women are more likely to work as paid employees or employers whereas rural women are engaged in vulnerable employment. It is generally observed that in developing economies, most of the women are engaged in the informal sector thus they have to suffer from decent employment deficit. Similarly, like Pakistan, in many other developing economies, every state or province is different in terms of development. There are states or provinces which are developed as compared to others. In Pakistan, the same notion is true. Punjab is the most developed province of the country therefore we have seen that most of the women are fulfilling the requirement of decent work in the Punjab province as compared to three other provinces.

There are interesting insights concerning the gender of household heads that in femaleheaded households, there is more probability that women are working as "EMPLEE" and OAW. Still, there is less probability that they are working as EMP or CFW. The total number of kids of age five years or less negatively affects a woman's employment status as a paid employee and a contributing family worker. Our findings align with the previous studies such as (He and Zhu 2016; Varol 2017). However, it is positively correlated with women's employment status if women work as CFW or EMP.

Family setup in Pakistani society plays a critical role for working women. In every employment status as compared to base category nuclear family system, the joint family system is positively associated with women's employment status. This may happen because women can share household responsibilities with other members of the family, and they can spare more time for the labor market activities (Naqvi and Shahnaz 2002; Faridi et al. 2009).

Education is an essential determinant of women's employment status. We found a vast literature supporting this notion (Kanjilal-Bhaduri and Pastore 2018; Klasen and Pieters 2015; Sefiddashti et al. 2016). We divided the education of women into seven categories 
to see the impact of every level of education on every employment status for effective policy outcomes. In the case of EMPLEE, compared to the base category of no formal education, there is more probability that women with higher secondary, graduation, and above graduation levels of education are working as EMPLEE.

Compared to the base category of no formal education, women have matric, above intermediate graduation, or higher levels of education. There is a more probability that women are working as EMP. The situation is quite the opposite in the case of OAW and CFW. In both employment statuses, compared to any other level of education, women with no formal education have more probability that they work either as OAW or as CFW as compared to the base category. Our empirical findings are aligned with the human capital theory (Becker 1975), which illustrates that investment in education is connected with better employment opportunities and higher earnings. Further, our results are providing few important insights with respect to decent employment. From the empirical findings, we infer that education is an essential channel to empower women and help them to opt for better employment statuses. Besides Pakistan, these empirical findings are equally valid for other developing economies. If developing economies intend to adapt the decent work agenda of the ILO, then they must initiate different policies to encourage women to invest in education.

The household head has a critical role in women's decisions to opt for any employment status. If the household head education is ten years or higher, women are more likely to be engaged in paid employment. The same is true for those women who are working as EMP. Still, if the heads of the households possess no formal education as compared to any other level of education, then there are more chances that women are engaged either as CFW or as OAW as compared to their not working counterparts. Our second hypothesis is related to the head of the household's level of education. We can infer from the empirical findings that if the head of the household is highly educated then there are more chances that women are engaged in non-vulnerable employment. The reason behind these findings is straightforward. More educated heads of the household encourage women to opt for better employment status. On the contrary, if the head of the household is working in vulnerable employment then there are more chances that a woman is also engaged in vulnerable employment. Therefore, the education of the head of the household is playing an important role for a woman to be engaged in decent employment.

Moreover, it is evident from the analysis that there is a more probability for women to be engaged as EMPLEE if their household heads are also working as EMPLEE. If women work as EMP then there is more probability that their heads of the households work as CFW. Women with the employment category of OAW and CFW have more chances that their heads of the households are either working as OAW or CFW. The analysis reveals that the head's employment status is essential in Pakistani society because most women opt for the same employment status as their fathers or heads.

As to the impact of migration on the employment status of women, it is found that migration is only significantly affecting women's employment status when women are working either as OAW or CFW (Fuchs et al. 2016; Sefiddashti et al. 2016). On similar lines, we see that technical/vocational training positively affects the choice of any employment status of a woman (Aslam and Rawal 2013; Torun and Tumen 2019). Compared to not working women, household size negatively affects the women's choice of opting for any employment status except for CFW in our selected sample (Usman and Sanusi 2016). 
Table 3. Multinomial Logit estimates of the employment status of women aged 15 to 65 .

\begin{tabular}{|c|c|c|c|c|}
\hline Explanatory Variables & EMPLEE & EMP & OAW & CFW \\
\hline \multicolumn{5}{|c|}{ Women's Characteristics } \\
\hline Age & $\begin{array}{c}0.165^{* * *} \\
(0.044)\end{array}$ & $\begin{array}{l}0.106^{* *} \\
(0.079)\end{array}$ & $\begin{array}{c}0.178^{* * *} \\
(0.042)\end{array}$ & $\begin{array}{c}0.075^{* * *} \\
(0.020)\end{array}$ \\
\hline Agesq & $\begin{array}{c}-0.001 \text { *** } \\
(0.000)\end{array}$ & $\begin{array}{c}-0.001 \text { *** } \\
(0.000)\end{array}$ & $\begin{array}{c}-0.002 \text { *** } \\
(0.001)\end{array}$ & $\begin{array}{c}-0.001 \text { *** } \\
(0.000)\end{array}$ \\
\hline Married & $\begin{array}{c}-0.724^{* * *} \\
(0.241)\end{array}$ & $\begin{array}{c}-0.651^{* * *} \\
(0.216)\end{array}$ & $\begin{array}{c}0.360^{* * *} \\
(0.072)\end{array}$ & $\begin{array}{c}0.329 * * * \\
(0.066)\end{array}$ \\
\hline Prim & $\begin{array}{c}-0.479 * * * \\
(0.133)\end{array}$ & $\begin{array}{l}-0.682 \\
(0.517)\end{array}$ & $\begin{array}{c}-0.387^{* * *} \\
(0.097)\end{array}$ & $\begin{array}{c}-0.301 \text { ** } \\
(0.151)\end{array}$ \\
\hline Mid & $\begin{array}{c}-0.595^{* * *} \\
(0.163)\end{array}$ & $\begin{array}{c}-0.712 \\
(0.561)\end{array}$ & $\begin{array}{c}-0.525^{* * *} \\
(0.111)\end{array}$ & $\begin{array}{c}-0.336 \\
(0.271) \\
\end{array}$ \\
\hline Secondary & $\begin{array}{c}-0.195^{* * *} \\
(0.050)\end{array}$ & $\begin{array}{c}0.521 \\
(0.469) \\
\end{array}$ & $\begin{array}{c}-0.702 \text { *** } \\
(0.181)\end{array}$ & $\begin{array}{c}-0.431 \text { ** } \\
(0.201)\end{array}$ \\
\hline HS & $\begin{array}{c}0.713^{* * *} \\
(0.178)\end{array}$ & $\begin{array}{c}0.412 \\
(0.375)\end{array}$ & $\begin{array}{c}-0.810^{* * *} \\
(0.166)\end{array}$ & $\begin{array}{c}-0.551 \text { ** } \\
(0.274)\end{array}$ \\
\hline Grad & $\begin{array}{c}0.722^{* * *} \\
(0.187\end{array}$ & $\begin{array}{c}0.331^{* * *} \\
(0.107)\end{array}$ & $\begin{array}{c}-0.828^{* * *} \\
(0.180)\end{array}$ & $\begin{array}{c}-0.591 \text { ** } \\
(0.290)\end{array}$ \\
\hline Tertiary & $\begin{array}{c}0.861^{* * *} \\
(0.168)\end{array}$ & $\begin{array}{c}0.672 * * * \\
(0.165)\end{array}$ & $\begin{array}{c}-0.870 * * \\
(0.395)\end{array}$ & $\begin{array}{c}-0.634^{* * *} \\
(0.164)\end{array}$ \\
\hline TVT & $\begin{array}{c}0.133^{* * *} \\
(0.029)\end{array}$ & $\begin{array}{l}0.503 * * \\
(0.228)\end{array}$ & $\begin{array}{l}0.333^{* *} \\
(0.162)\end{array}$ & $\begin{array}{c}0.129 * * * \\
(0.033)\end{array}$ \\
\hline Local & $\begin{array}{l}0.133 * \\
(0.071)\end{array}$ & $\begin{array}{c}0.691 \\
(0.684)\end{array}$ & $\begin{array}{c}0.210 * * * \\
(0.070)\end{array}$ & $\begin{array}{c}0.436 \text { *** } \\
(0.099)\end{array}$ \\
\hline \multicolumn{5}{|c|}{ Head of Household Characteristics } \\
\hline Female & $\begin{array}{c}0.761^{* * *} \\
(0.171)\end{array}$ & $\begin{array}{l}-0.505 \\
(0.417)\end{array}$ & $\begin{array}{c}0.632 * * * \\
(0.172)\end{array}$ & $\begin{array}{c}-0.672 \text { *** } \\
(0.184)\end{array}$ \\
\hline Age & $\begin{array}{c}-0.004^{* * *} \\
(0.001)\end{array}$ & $\begin{array}{l}-0.002 \\
(0.002)\end{array}$ & $\begin{array}{c}-0.007^{* * *} \\
(0.002)\end{array}$ & $\begin{array}{c}-0.001 \\
(0.001) \\
\end{array}$ \\
\hline Some Education & $\begin{array}{c}-0.2011^{* * *} \\
(0.039)\end{array}$ & $\begin{array}{c}0.527 * * * \\
(0.175)\end{array}$ & $\begin{array}{c}-0.089 * \\
(0.051)\end{array}$ & $\begin{array}{c}-0.234^{* * *} \\
(0.053)\end{array}$ \\
\hline 10 years or more Edu & $\begin{array}{c}0.330 * * * \\
(0.096)\end{array}$ & $\begin{array}{c}0.644^{* * *} \\
(0.161)\end{array}$ & $\begin{array}{c}-0.522^{* * *} \\
(0.130)\end{array}$ & $\begin{array}{c}-0.579 * * * \\
(0.145)\end{array}$ \\
\hline Emp & $\begin{array}{c}-0.318^{*} \\
(0.186)\end{array}$ & $\begin{array}{c}0.524 \\
(0.468) \\
\end{array}$ & $\begin{array}{c}0.118 \\
(0.110) \\
\end{array}$ & $\begin{array}{l}0.211 * \\
(0.119)\end{array}$ \\
\hline Emplyd & $\begin{array}{c}0.552^{* * *} \\
(0.138)\end{array}$ & $\begin{array}{c}0.256 \\
(0.210)\end{array}$ & $\begin{array}{c}0.230 \\
(0.202)\end{array}$ & $\begin{array}{c}0.277 \\
(0.192) \\
\end{array}$ \\
\hline Own account & $\begin{array}{l}0.483 * \\
(0.267)\end{array}$ & $\begin{array}{c}-0.518 * \\
(0.303)\end{array}$ & $\begin{array}{c}0.294^{* * *} \\
(0.060)\end{array}$ & $\begin{array}{c}0.666^{* * *} \\
(0.177)\end{array}$ \\
\hline Contributing workers & $\begin{array}{c}0.418 * * \\
(0.204)\end{array}$ & $\begin{array}{c}0.661^{* * *} \\
(0.193)\end{array}$ & $\begin{array}{l}0.217^{* *} \\
(0.108)\end{array}$ & $\begin{array}{c}0.688^{* * *} \\
(0.229)\end{array}$ \\
\hline \multicolumn{5}{|c|}{ Family Characteristics: } \\
\hline HH size & $\begin{array}{c}-0.016^{* * *} \\
(0.004)\end{array}$ & $\begin{array}{l}-0.159 \\
(0.143)\end{array}$ & $\begin{array}{l}-0.008 \\
(0.006)\end{array}$ & $\begin{array}{l}0.007 * \\
(0.004)\end{array}$ \\
\hline Kids & $\begin{array}{c}-0.149 * * * \\
(0.027)\end{array}$ & $\begin{array}{l}0.321 * \\
(0.174)\end{array}$ & $\begin{array}{c}0.002 \\
(0.002) \\
\end{array}$ & $\begin{array}{l}-0.037 \\
(0.033)\end{array}$ \\
\hline Joint & $\begin{array}{c}0.192^{* * *} \\
(0.048)\end{array}$ & $\begin{array}{c}0.473 \\
(0.468)\end{array}$ & $\begin{array}{c}0.025 \\
(0.020)\end{array}$ & $\begin{array}{c}0.075^{* * *} \\
(0.017)\end{array}$ \\
\hline
\end{tabular}


Table 3. Cont.

\begin{tabular}{ccccc}
\hline Explanatory Variables & EMPLEE & EMP & OAW & CFW \\
\hline \multirow{2}{c}{ Region } & & \\
\hline \multirow{2}{*}{ Urban } & $0.386^{* * *}$ & 0.113 & $-0.569^{* * *}$ & $-0.555^{*}$ \\
& $(0.077)$ & $(0.093)$ & $(0.100)$ & $(0.308)$ \\
\hline \multirow{2}{*}{ Punjab } & $0.661^{* * *}$ & $0.207^{*}$ & $0.143^{* * *}$ & $0.844^{* * *}$ \\
& $(0.090)$ & $(0.111)$ & $(0.024)$ & $(0.253)$ \\
\hline \multirow{2}{*}{ Sindh } & $0.459^{* * *}$ & -0.089 & $0.711^{* *}$ & 0.013 \\
& $(0.096)$ & $(0.080)$ & $(0.354)$ & $(0.011)$ \\
\hline \multirow{2}{*}{ KPK } & $0.350^{* * *}$ & -0.196 & $-0.140^{* *}$ & $-0.608^{* *}$ \\
& $(0.116)$ & $(0.194)$ & $(0.070)$ & $(0.297)$ \\
\hline
\end{tabular}

Source: LFS 2017-2018. Not working nor seeking work is the base category. ${ }^{* * *},{ }^{* *},{ }^{*}$ significant at $1 \%, 5 \%$ and $10 \%$ respectively. Standard errors in parenthesis.

\section{Research Implication, Limitations, and Conclusions}

In this research, we analyzed the crucial factors that are associated with different employment statuses of women. We adapted the standardized categorization of women's employment status into four categories, EMPLEE, EMP, OAW, and CFW. In contrast, our base category is women not working nor seeking work. Our study concluded that the woman's age is following an inverted U-shape pattern in each of the employment statuses. Married women are more likely to work as OAW and CFW. However, there is a lower probability for women to be EMP or EMPLEE if they are married. As married women are required to spend more time in the household due to child-rearing and other household responsibilities, therefore, there is a reason to believe that married women are less likely to take up decent work opportunities because of the extra care they need to provide to the household as a married woman. On the other hand, there is a higher probability of married women being part of vulnerable employment groups.

Education is the key explanatory variable in this research to analyze the model of the employment status among women. Based on the results presented in the previous section, it is concluded that a higher level of education-more than higher secondary educationleads to women being engaged in decent work categories of employer and paid employee. However, women with a lower level of education, i.e., secondary education and below, are less likely to be part of any of the employment categories. This finding leads us to confirm that a higher level of education among women is essential in making them part of decent work categories. The reason is straightforward that a higher level of education is considered an indicator of high human capital. Therefore, if a woman possesses higher education, she is more likely to be offered opportunities to be part of a decent work where she can enjoy equitable working rights such as equal wage and access to social security contributions.

Concerning technical/vocational training, which is also one of the indicators of human capital, it is positively associated with all the employment statuses of women. It is more likely for locally residing women to be engaged as EMPLEE, OAW, and CFW than those who migrate from other provinces. In female-headed households, employed women are more likely to work as EMPLEE and unpaid/CFW. We also included the education and employment status of the head of the household. We find that as the head's education level increases, there are fewer chances that women are engaged as OAW or CFW. If heads of the households work as EMPLEE then there is more probability that women also work as EMPLEE. In the case of women work as EMP, then there is more probability that their heads of the households work as CFW. For women who are working as OAW and CFW, there are more chances that their heads of the households are also working as OAW or CFW. Household size is negatively affecting the women's choice of opting for any employment status except for CFW. Urban women are more likely to be engaged as EMPLEE or EMP. Compared to not working women, most women working as EMPLEE, OAW, and CFW are residing in the Punjab province. 
On the policy front, the study offers two policy recommendations based on empirical results. Women need to invest in education and vocational training as education is the key to open better and decent work opportunities. Secondly, it is essential to change the perception of women's education at the household level. In the long run, it should be made possible through policy change that every woman should have access to at least a higher secondary level of education in Pakistan. The rationale is that less educated and illiterate women are concentrated in vulnerable employment. Moreover, most of the time head of the household who is earning well does not allow women to explore labor market opportunities. Therefore, it is vital to initiate a campaign through social and mass media where the male head of the household is the target to make them realize that it is important to encourage women to take part in labor market activities.

The empirical findings of this research are subject to a few limitations. The first limitation is concerned with the identification of the true causal effect of education on employment outcomes. Our empirical model may be susceptible to endogeneity bias due to the presence of reverse causality between education and employment, i.e., women engaged in decent work categories may be tempted to acquire higher education in pursuit of further growth in their careers. In other words, this study finds a strong positive association between education and employment outcomes for women, however, the available data do not permit us to identify the true direction of this relationship. There may be the case that a woman's choice to get involved in decent work motivates her to get higher education, or a highly educated woman is more likely to be employed as a decent worker. The issue can be resolved by employing methodological techniques of causal inference such as the Instrumental Variable (IV) or quasi-experimental Regression Discontinuity Design (RDD) in future research. The researcher can exploit IV with a strong instrumental variable that fulfills the relevance and exclusion restriction as proposed by Wooldridge (2013). Second, the dataset used for analysis is cross-sectional labor force survey data. The results would have been more consistent if the results were estimated through longitudinal data. This is because longitudinal data allows the effect of a certain phenomenon on a consistent sample across several time periods. Moreover, the policy implications derived from longitudinal data are strongly applicable.

Author Contributions: Conceptualization, M.S. and Z.A.; methodology, M.S.; software, M.K.; validation, M.K., Z.A. and N.U.K.; formal analysis, H.A.B.; investigation, N.U.K.; resources, M.S.; data curation, Z.A.; writing — original draft preparation, M.S.; writing—review and editing, N.U.K. and H.A.B.; visualization; project administration. All authors have read and agreed to the published version of the manuscript

Funding: This research received no external funding.

Institutional Review Board Statement: Not applicable.

Informed Consent Statement: Not applicable.

Data Availability Statement: The data presented in this study are available on request from the corresponding author.

Conflicts of Interest: The authors declare no conflict of interest.

\section{Note}

See (Greene 2000) Greene, William H. 2000. Econometric Analysis, 4th ed. International Edition. Hoboken: Prentice Hall, pp. 201-15.

\section{References}

Abu-Hummour, Anan. 2021. Evaluation study of Jordan's Decent Work Country Programme from 2012 to 2015. International Journal of Management Practice 14: 217-39. [CrossRef]

Aly, Hassan Youssef, and Issa Al-Quisi. 1996. Determinants of women's labour force participation in kuwait: A logit analysis. Middle East Business and Economic Review 8: 1-9. 
Andlib, Zubaria, and Aliya Hassan Khan. 2018. Low Female Labor Force Participation in Pakistan: Causes and Factors. Global Social Sciences Review 3: 237-64. [CrossRef]

Andlib, Zubaria, and Aliya Hassan Khan. 2019. The Paradox of Out of Labor Force Educated Women in Pakistan: Evidence from PSLM 2013-2014 Household Survey. Journal of Humanities $\mathcal{E}$ Social Sciences (Pakistan) 27: 201-18.

Aslam, Monazza, and Shenila Rawal. 2013. Preparing Women of Substance? Education, Training, and Labor Market Outcomes for Women in Pakistan. Lahore Journal of Economics 18: 93-128. [CrossRef]

Assaad, Ragui, and Sami Zouari. 2003. Estimating the impact of marriage and fertility on the female labor force participation when decisions are interrelated: Evidence from urban Morocco. Topics in Middle Eastern and North African Economies 5: 1-37.

Becker, Gary Stanley. 1965. A Theory of the Allocation of Time. The Economic Journal 75: 493-517. [CrossRef]

Becker, Gary Stanley. 1975. Investment in human capital: Effects on earnings. In Human Capital: A Theoretical and Empirical Analysis, with Special Reference to Education, 2nd ed. Cambridge: National Bureau of Economic Research, pp. 13-44.

Bhalla, Surjit, and Ravinder Kaur. 2011. Labour Force Participation of Women in India: Some Facts, Some Queries. Working Paper 40. London: Asia Research Centre, London School of Economics and Political Science.

Blau, Francine Dee, Marianne A. Ferber, and Anne E. Winkler. 2005. The Economics of Women, Men and Work, 5th ed. Portland: Taylor \& Francis.

Blundell, Richard, Lorraine Dearden, Costas Meghir, and Barbara Sianesi. 1999. Human capital investment: The returns from education and training to the individual, the firm and the economy. Fiscal Studies 20: 1-23. [CrossRef]

Bradbury, Katharine L., and Jane Katz. 2005. Women's rise: A work in progress. Regional Review, 58-67.

Che, Gladys Njang, and Fabien Sundjo. 2018. Determinants of female labour force participation in Cameroon. International Journal of Applied Economics, Finance and Accounting 3: 88-103. [CrossRef]

Ejaz, Mehak. 2007. Determinants of Female labor force participation in Pakistan: An empirical analysis of PSLM (2004-2005) Micro data. The Lahore Journal of Economics 12: 203-35. [CrossRef]

Faridi, Muhammad Zahir, Shahnawaz Malik, and A. B. Basit. 2009. Impact of Education on Female Labour Force Participation in Pakistan: Empirical Evidence from Primary Data Analysis. Pakistan Journal of Social Sciences (PJSS) 29: 127-40.

Finlay, Jocelyn E. 2021. Women's reproductive health and economic activity: A narrative review. World Development $139: 105313$. [CrossRef]

Fuchs, Johann, Alexander Kubis, and Lutz Schneider. 2016. Replacement Migration from a Labour Market Perspective: Germany's Long-Term Potential Labour Force and Immigration from Non-EU Member Countries. IAB-Discussion Paper, No. 4/2016. Nürnberg: Institut für Arbeitsmarkt- und Berufsforschung (IAB).

GoP. 2018. Labor Force Survey. Edited by Pakistan Bureau of Statistics. Islamabad: Government of Pakistan.

Gray, Matthew, Alexandra Heath, and Boyd Hunter. 2002. An Exploration of Marginal Attachment to the Australian Labour Market. Sydney: Economic Research Department, Reserve Bank of Australia.

Greene, William H. 2000. Econometric Analysis, International Edition, 4th ed. Hoboken: Prentice Hall, pp. 201-15.

Hafeez, Amtul, and Eatzaz Ahmad. 2002. Factors determining the labour force participation decision of educated married women in a district of Punjab. Pakistan Economic and Social Review 40: 75-88.

He, Xiaobo, and Rong Zhu. 2016. Fertility and Female Labour Force Participation: Causal Evidence from Urban China. The Manchester School 84: 664-74. [CrossRef]

ILO. 2008. Global Employment Trends-January 2008. Geneva: International Labor Office.

ILO. 2016. Women at Work: Trends 2016. Geneva: International Labour Office.

Kanjilal-Bhaduri, Sanghamitra, and Francesco Pastore. 2018. Returns to education and female participation nexus: Evidence from India. The Indian Journal of Labour Economics 61: 515-36. [CrossRef]

Khoudja, Yassine, and Fenella Fleischmann. 2015. Ethnic differences in female labour force participation in the Netherlands: Adding gender role attitudes and religiosity to the explanation. European Sociological Review 31: 91-102. [CrossRef]

Klasen, Stephan, and Janneke Pieters. 2015. What explains the stagnation of female labor force participation in urban India? The World Bank Economic Review 29: 449-78. [CrossRef]

Lechman, Ewa, and Harleen Kaur. 2015. Economic growth and female labor force participation-verifying the U-feminization hypothesis. New evidence for 162 countries over the period 1990-2012. New Evidence for 162: 1990-2012.

Lee, Bun Song, Soomyung Jang, and Jayanta Sarkar. 2008. Women's labor force participation and marriage: The case of Korea. Journal of Asian Economics 19: 138-54. [CrossRef]

Mitra, Aparna, and Pooja Singh. 2006. Human capital attainment and female labor force participation-The Kerala puzzle. Journal of Economic Issues 40: 779-98. [CrossRef]

Naqvi, Zareen F., and Lubna Shahnaz. 2002. How do women decide to work in Pakistan? The Pakistan Development Review 41: 495-513. [CrossRef]

Ntuli, Miracle. 2007. Determinants of South African Women's Labour Force Participation, 1995-2004. Bonn: Institute for Study of Labor (IZA).

Osterreich, Shaianne T. 2020. Gender, Decent Work, and Global Production Sharing in Indonesian Manufacturing. Journal of Economic Issues 54: 54-76. [CrossRef]

Pignatti, Norberto, Karine Torosyan, and Maka Chitanava. 2017. Toothless Reforms? The Remarkable Stability of Female Labor Force Participation in a Top-Reforming Country. Working Papers 003-17. Tbilisi: International School of Economics at TSU. 
Qian, Nancy. 2008. Missing women and the price of tea in China: The effect of sex-specific earnings on sex imbalance. The Quarterly Journal of Economics 123: 1251-85. [CrossRef]

Saha, Paramita, and Mamoni Kalita. 2015. Determinants of female work participation and labour supply behaviour of urban women in Tripura: A logit estimation. Social Change and Development 22: 77-87.

Sefiddashti, Sara Emamgholipour, Enayatollah Homaie Rad, Arab Mohamad, and Shima Bordbar. 2016. Female Labor Supply and Fertility in Iran: A Comparison Between Developed, Semi Developed and Less Developed Regions. Iranian Journal of Public Health 45: 186.

Shaheen, Ruqia, Ghulam Shabir, Muhammad Zahir Faridi, and Fouzia Yasmin. 2015. Determinants of female employment status in Pakistan: A case of Sahiwal District. Pakistan Journal of Commerce and Social Sciences (PJCSS) 9: 418-37.

Torun, Huzeyfe, and Semih Tumen. 2019. Do Vocational High School Graduates Have Better Employment Outcomes Than General High School Graduates? International Journal of Manpower 40: 1364-88. [CrossRef]

UN. 1997. Handbook for Producing National Statistical Reports on Women and Men. New York: Statistics Division, United Nations.

UN Women Pakistan. 2016. Women's Economic Participation E Empowerment in Pakistan-Status Report. Islamabad: UN Women Pakistan.

UNDP. 2017. Pakistan National Human Development Report: Unleashing the Potential of a Young Pakistan. Islamabad: United Nations Development Program.

Uraz, Arzu, Meltem Aran, Müşerref Hüsamoğlu, Dilek Okkalı Şanalmış, and Sinem Çapar. 2010. Recent Trends in Female Labor Force Participation in Turkey. Working Paper No. 2. Ankara: World Bank.

Usman, Ojonugwa, and Abdussamad Sanusi. 2016. Education and Labor Force Participation of Women in North Cyprus: Evidence from Binomial Logit Regression Model. MPRA Paper 77140. Munich: University Library of Munich.

Varol, Fatih. 2017. The determinants of labor force participation of women in Turkey: A binary logit analysis. Journal of History Culture and Art Research 6: 92-108. [CrossRef]

Wooldridge, Jeffrey M. 2013. Introductory Econometrics: A Modern Approach. Mason: Cengage Learning.

World Bank. 2017. World Development Indicators 2017. Washington, DC: World Bank. 